wing bright yellow. Pleuræ shining black without yellow markings, a brown spot on mesopleuræ, upper pteropleuræ and on the metapleuræ. Scutellum yellow with a narrow brown transverse band. Dorsum papillosetose with a transverse stripe along the suture, not connected medianly.

First abdominal segment dark reddish, with a black spot in the middle above and on either side and with a narrow posterior black border. Second segment black, on the sides and posteriorly dark red, anteriorly yellow; very much constricted. Remaining segments shining black with deep red posterior border and prominent gray pollinose lunules.

Legs shining red, the basal half of all the tibiæ becoming pale yellow, and the femora basally, paler in color. Halteres and squamæ brownish yellow. Wings dark brown on the whole anterior half the infuscation, reaching to the tip of wing or end of costa.

Type, female and three paratypes, females, Dilley, Texas, May 4-11, 1920 (H. J. Reinhard).

This interesting form is certainly related to bellardi in the pattern of the pleuræ, thorax, and abdomen. However, the several specimens of this species differ from that species in a number of points. Among them are the face with its papillosetæ and its peculiar bulges, and the ventral concavity of the abdomen with the unusual shape of the last two abdominal segments. Structurally it would appear nearest related to schwarzi Shnn. The shining, glossy black of schwarzi Shnn. renders that species abundantly distinct.

\title{
NOTES ON THE PREY OF WASPS
}

\section{BY RICHARD Dow}

The first three records are based on specimens in the collection of Dr. J. Bequaert, who has kindly permitted me to publish on his material. I am also indebted to Prof. N. Banks, Mr. C. W. Johnson, and Mr. Wm. T. Davis for assistance in determining specimens. 
Ageniella accepta (Cress.)

Lycosa sp., immature [N. Banks]

Riverhead, L. I., N. Y.; Aug. 1, 1917; Wm. T. Davis

It is customary for the species of Ageniella and Pseudagenia to mutilate their spiders by removing the legs. The present spider forms no exception, as all eight legs have been nipped off at the coxæ. According to Hartman (Bull. Univ. Texas 65:47. 1905), this Psammocharid also preys on Attids.

Crabro (Thyreopus) argus Pack.

Rhaphium vanduzeei Curran [C. W. Johnson]

White Plains, N. Y.; Sept. 10, 1921

This is apparently the first reference to the prey of the above wasp. The fly has been described since the compilation of the New York list.

\section{Tachytes mandibularis Patt.}

Conocephalus saltans (Scud.) [Wm. T. Davis]

White Plains, N. Y.; Sept. 10, 1921

Orchelimum fidicinium Rehn \& Hebard [Wm. T. Davis]

Oyster Bay, L. I., N. Y.; Aug. 31, 1929

In the case of the second record, the wasp was flying with the Orchelimum, and both were caught in one sweep of the net. The wasp was killed, but the grasshopper was brought back to the laboratory for observation. Two days later it was still alive, and when stimulated, moved the abdomen, the antennæ, and both pairs of palpi. That evening and also the next morning, it was moving the antennæ and palpi spontaneously. The following morning (Sept. 4), it waś dead.

When Patton described T. mandibularis (Ent. News $3: 90$. 1892), he gave the prey as Xiphidium (now Conocephalus). F. X. Williams found it preying on an immature Orchelimum (Kans. Univ. Sci. Bull. 8:198, 1913), and Wm. T. Davis has an additional record for Orchelimum fidicinium in the New York list (p. 23). 

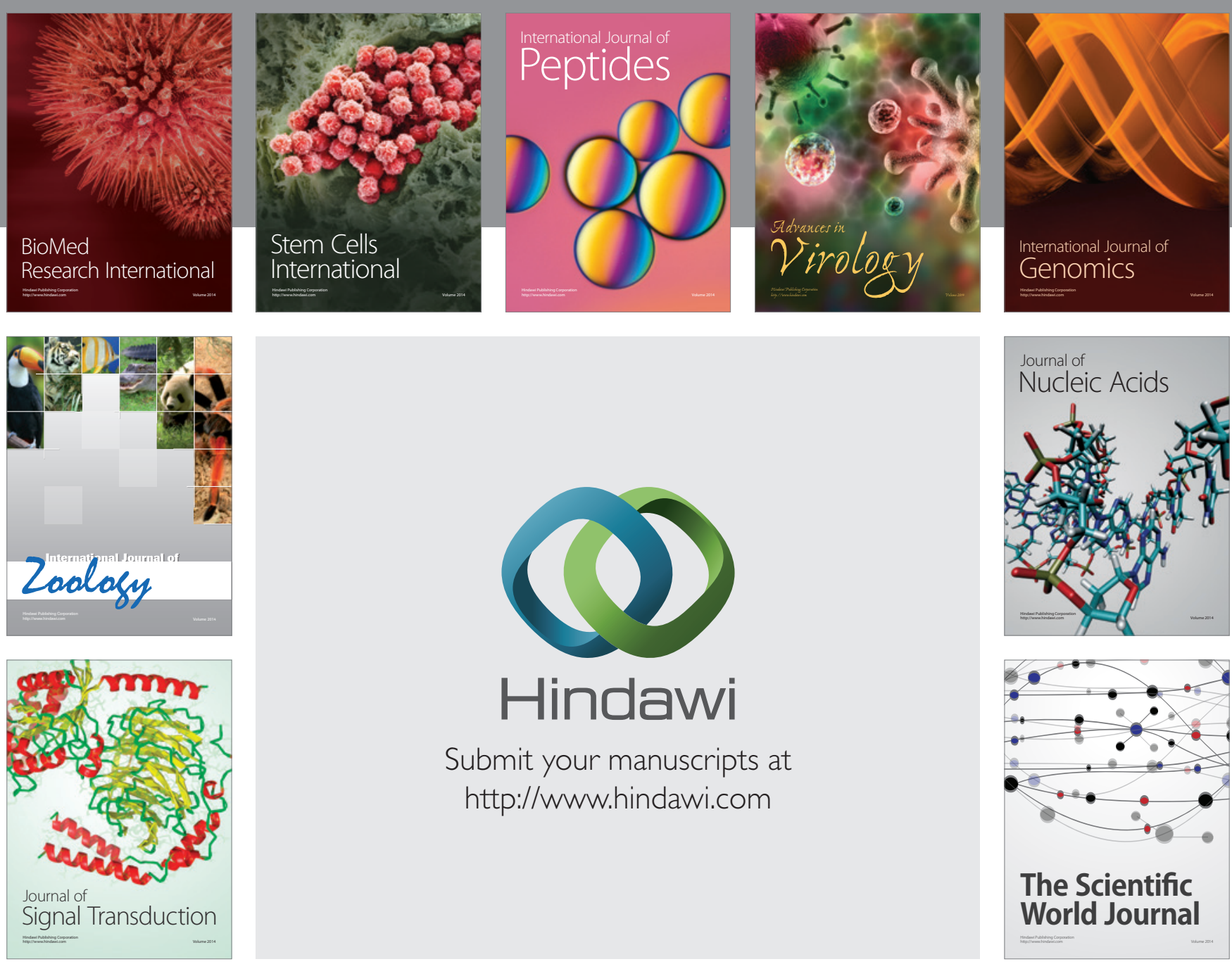

Submit your manuscripts at

http://www.hindawi.com
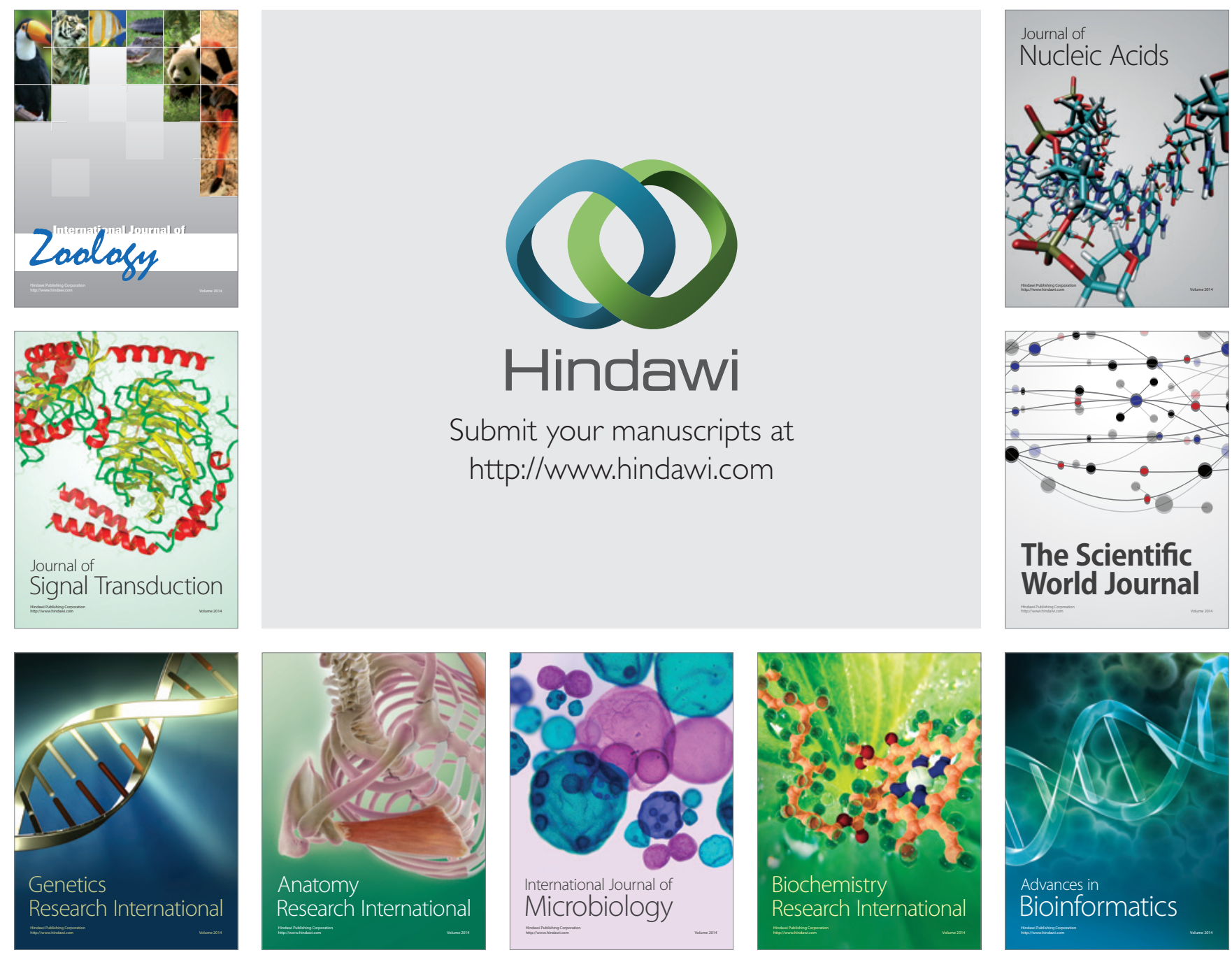

The Scientific World Journal
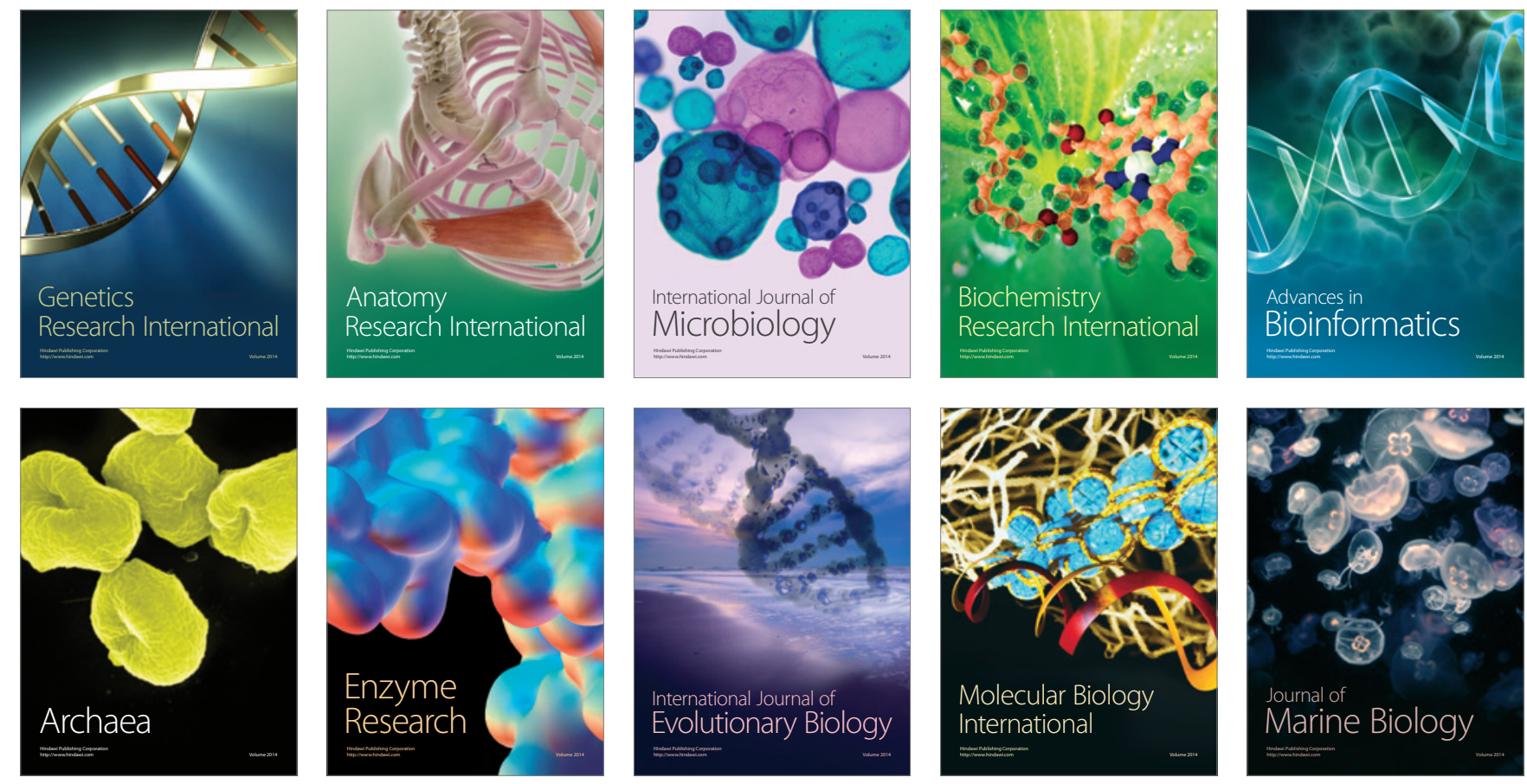